\title{
Participative Budgeting, Budgetary Slack And Job Satisfaction In The Public Sector
}

\author{
Suleman H. A. Kahar, Diponegoro University \& University of Khairun, Ternate, North Maluku, Indonesia \\ Abdul Rohman, Diponegoro University, Indonesia \\ Anis Chariri, Diponegoro University, Indonesia
}

\begin{abstract}
This study explores the relationship of participative budgeting on budgetary slack in the public sector in Indonesia, by examining the roles of job satisfaction on these variables. A total of 185 budget managers of regional work units in the in North Maluku province government, Indonesia, participated in the survey. The effective rate of return was 82.52 percent. A structural equation modeling was used to examine the direct and indirect effects of participative budgeting on budgetary slack. In particular, the study gives empirical evidences that participative budgeting factors affect budgetary slack mediated by intervening variables factors of job satisfaction. The results revealed the significantly negative effect of participative budgeting on budgetary slack, the significantly positive effect of participative budgeting on job satisfaction. This result affirmed the significantly negative impact of job satisfaction as a mediating variables on budgetary slack. However, the results could not find the indication of moderating effect of job satisfaction in the relationship of these variables.
\end{abstract}

Keywords: Participative Budgeting; Job Satisfaction; Budgetary Slack

\section{INTRODUCTION}

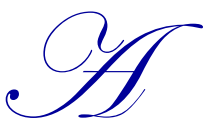

critical element in the system of management control is the budget. A budget is a management tool in allocating limited resources owned by the organization to achieve the goal. Kenis (1979) describes the budget is not only a financial plan regarding costs and revenues in a central responsibility, but also serves as a means of control, coordination, communication, performance evaluation and motivation.

Budgets can also be regarded as statements regarding the estimation of performance to be achieved during a certain period of time in the size of the financial. Budgeting in the public sector, a process that is quite complex and contains political content. In contrast to the budget on political burden of the private sector may be relatively smaller. In line with the authority granted by the central government to municipalities and counties to regulate household, resulting in the local government officials, especially officials of echelon to be involved in determining the direction and policy of regional development. One form of embodiment to be aware of such involvement is participation in the preparation of the regional budget.

Participative Budgeting is a process joint decision-making by the public sector is an instrument of accountability for management and implementation of programs financed from public funds. The budget related to the public sector in the process of determining the amount of the allocation of funds for each program and activity in monetary units. Stage budget becomes very important because ineffective budget and not performance oriented may thwart plans that have been prepared (Mardiasmo, 2002).

Budgeting participative is a process that describes the individuals involved in budgeting and has an influence on budget targets and the necessity of awards for budget achievement (Brownell, 1982). An issue arising from the involvement of the lower or middle level managers in the preparation of the budget is the creation of budgetary slack. Budgetary slack is usually done with elevating costs or lower revenues than it should, so that the budget be easily achieved (Merchant, 1985). 
Budget involves human relationships, and then there is a human behavior that may arise as a result of the budget, both positive behaviors and negative behaviors. Positive behavior can be performance improvement manager motivated by the budget used as the basis for the assessment of their performance. Negative behavior that may arise is the emergence of the notion that the budget is often seen as a tool of managerial pressure. Middle and lower level managers feel the pressure when the top management seeks to improve efficiency by getting more output from existing input level (or lower) so that managers tend to create slack in the budget in order to increase the possibility to meet or exceed the performance standards.

Budgetary slack is defined as the difference between the real resources needed to complete the work effectively with a number of resources that are added to complete the task (Siegel and Marconi, 1989). Manager creates slack by estimating lower income, higher cost estimating, or declare too high number of inputs required to produce a unit of product. They do this to provide a safety margin to fulfill budgeted goals.

Some accounting researchers found that the level of budgetary slack is influenced by several factors, including the magnitude of the subordinate role or participation in the preparation of the budget. The results of previous studies, which examine the correlation between subordinate participation by budgetary slack showed inconsistent results. Onsi (1973), Cammann (1976), Merchant (1985), Dunk (1993) Kren (2003), Maiga (2005), Maiga and Jacobs (2008) and Husain (2011), Husain (2014) showed that participative budgeting reduce the number of budgetary slack. While Yuwono (1998), Lukka (1988), Young (1985), Basri (2010) Djasuli and Fadila (2011), as well as Jaya and Rahardjo (2013) showed the opposite result. Their results show participative budgeting and budgetary slack have a positive correlation. Collins (1978) and Vemy et al. (2011) in his research made a conclusion that the participative budgeting with budgetary slack has insignificant correlation.

Various studies have been conducted to examine the factors that influence the emergence of slack as described above gives inconsistent results. Differences in the results of this study due to the diversity of variables mediating or moderating variables selected in the study. In analyzing the relationship between participative budgeting and budgetary slack, many studies linked working conditions factors experienced and responded by the individual in an organization. Chong, Eggleton, and Leong (2006), Jermias and Setiawan (2008), Nor Yahya, Nazli Nik Ahmad and Hamid Fatima (2008), Nouri and Parker (1998) have linked the roles of cognitive and motivational factors of participative budgeting on individual job performance. In particular, Chong, Eggleton, and Leong, (2006), LeachLópez, Stammerjohan and Sang Lee, (2009) stated that there is a strong evidence of relationship between participative budgeting toward individual performance with job satisfaction as intervening variable. Job satisfaction is an individual thing. Each individual has a level of satisfaction varies, as defined by Kreitner and Kinicki (2000), that job satisfaction as effectiveness or emotional response to various aspects of the job. This definition implies that job satisfaction is not a single concept, otherwise one can be relatively satisfied with some aspects of the job and not be satisfied with one or several other aspects. However, only a few intention used job satisfaction as the moderating as well as mediating variable to fill the theoretical gap revealed by previous studies in the explaining the relationship between participative budgeting and budgetary slack in the public sectors. For example, Nouri (1994) provided the empirical evidence the relationship of motivational factors of job involvement and organizational commitment toward decreased prospensity of budgetary slack. Therefore, the authors are interested in trying to do research back on the effect of participative budgeting to budgetary slack with job satisfaction as mediating and moderating variables.

\section{THEORY AND HYPOTHESIS DEVELOPMENT}

\subsection{Budget and Agency Theory}

Agency theory explains correlation between the two parties involved in the contract are consists of agents as the assigned responsibility and duty as a principle of the party giving the responsibility. This results consequence that the conditions of the participants, the agent and the principal will try to maximize their utility (Jensen and Meckling, 1976). The separation between the agent and the principal cause agency problems. This problem occurs because of a tendency to moral hazard management in maximizing their interests at the expense of principle. 
A budget is a tool of planning and control system so that the system of government can be done efficiently and effectively. In preparing the budget, there is an agency relationship between the executive members as agents and legislators as a principle. Budget is also a political contract document between the executive and legislators for the future (Mardiasmo 2002).

\subsection{Participative Budgeting and Budgetary Slack}

Quality budget is highly dependent on how the budget process. Budget is the sharing of information between subordinates and superiors that interact in participation. In the budget system, the manager role actively participate in the preparation of the budget is done. The process of public finance management began preparing the budget.

Mardiasmo (2002) stated that the form of autonomy of the state conducted through the use resources economically and efficiently to achieve public accountability. To achieve the appropriate budget needed first step in managing existing resources. Operationally, the budget prepared by the executive that would require legislative approval. The budget is used as a basis for evaluating the performance of the executive with the budget realization. The budget prepared by the regional work units. The budget is the basis for evaluating the performance of the regional work units next year (budget realization). In this case, the employee may commit budgetary slack to make the absorption realization easier. This attitude is also influenced by how a particular employee will keep the same position in the next year. The higher the degree of certainty (continuity position), then the chances are higher for them to create budgetary slack.

Halim and Abdullah (2008) suggests that in local government the possibility of creation budgetary slack is large enough. Budget activities (ranging from the classification of expenditure, the determination of cost standard, up to the amount of the budget must be provided) involving all implementers in the regional work units. Local Government Budget and Expenditure as a collection of budget many work units (Department, Agency, Bureau, Office, and the Secretariat) depends on the needs in each work unit. The needs of each business unit are different, different interests lead very complex conflict. Budgetary slack will occur when most of the determination of the allocation of the activities organized by political interests.

Slack on the local government budget occurred due to opportunistic behavior in the regional work units. Opportunistic behavior of the proposed activities actually not a priority, propose activities that have the opportunity to gain great personal, allocating expenditure component is too large for the components of expenditure and budget of each activity, and increase the budget for activities that are difficult to measure the results (Halim and Abdullah 2008).

\subsection{Previous Research and Hypothesis Development}

Some accounting researchers found that the level of budgetary slack is influenced by several factors, including the magnitude of the subordinate role or participation in the preparation of the budget. The results of previous studies, which examine the correlation between subordinate participation by budgetary slack showed inconsistent results. Research conducted Onsi (1973), Cammann (1976), Merchant (1985), Dunk (1993) Kren (2003), Maiga (2005), Maiga and Jacobs (2008) and Husain (2011), Husain (2014) shows that Participative Budgeting reduce the number of budgetary slack. While Yuwono (1998), Lukka (1988), Young (1985), Basri (2010) Djasuli and Fadila (2011), as well as Jaya and Rahardjo (2013) showed the opposite result. Their results show Participative Budgeting and budgetary slack have a positive correlation. Collins (1978) and Vemy et al. (2011) in his research made a conclusion that the Participative Budgeting with budgetary slack has insignificant correlation.

Research related to budgetary slack has tested a variety of factors that can affect the tendency of managers to create budgetary slack. Approaches used include the use of agency models to create budgetary slack, or by using a variety of factors as predictors of the budgetary slack (Govindarajan 1986). Although such approaches have helped shed light on the tendency of managers to create budgetary slack, but it is still an unanswered question.

Maiga (2005), Maiga and Jacobs (2008) examined the effect of participative budgeting and budgetary slack in moderation by equity moral and ethical judgment. The results showed that moral and ethical judgment equity may 
moderate the relationship between Participative Budgeting and budgetary slack. Ikhsan and Ane (2007) studied the effect of participative budgeting to budgetary slack with five moderating variable, shows the strategic uncertainty, the uncertainty of the environment, organizational commitment and leadership style that serves as a quasi-moderator.

Ozer and Yilmaz research (2011) using the perception of procedural Justice as mediation correlation budgetary control effectiveness and ethical work climate for managers create budgetary slack. The results showed that perception of procedural Justice into mediation budget control effectiveness correlation and budgetary slack significant negative.

This study uses a variable job satisfaction as mediation and moderation correlation between Participative Budgeting and budgetary slack. Budgetary slack in participation occurs budget when individuals know that their performance will be judged based budget realization. This situation motivates the individual to optimal in the budget preparation, then the hypothesis are:

$\mathbf{H}_{1}$ : Participation budget significant negative effect on budgetary slack

$\mathbf{H}_{2}$ : Participation budget significant positive effect on job satisfaction

$\mathbf{H}_{3}$ : Job satisfaction is significant negative effect on budgetary slack

$\mathbf{H}_{4}$ : Job satisfaction as variables mediating correlation between Participative Budgeting and budgetary slack

$\mathbf{H}_{5}$ : Job satisfaction as a moderating variable correlation between Participative Budgeting and budgetary slack

\section{RESEARCH METHODS}

\subsection{Population, Sample and Data Source}

This research was conducted at the Government Agencies in North Maluku province. The population in this study is the regional work units in the Provincial Government of North Maluku. The study was conducted for 3 Months began on 02 August to November, 2014. The study was conducted using a survey to Chief of regional work units, Secretary, Head of Planning / Head of Sub Division, Head of Equipment, Head of programming, and the head of equipment in North Maluku provincial government.

While the sample in this study was composed officials Head of regional work units, Secretary, Head of Planning/Head of sub department, Head of Equipment, Program Development Section, and the head of equipment involved in the preparation of work plan and budget of 41 regional work units.

By purposive sampling method, the researcher has the purpose or specific targets based on the considerations and criteria. The consideration is the respondents of this study is an officer who has a very big role in the process of preparation and use of the budget, in addition they also know more accurate information on the operational budget required to work on each unit. The sample in this study amounted to 246 respondents consisting of officers who participated in the preparation and budget users.

After sorting the data on respondents who returned found that there is one the regional work units did not return the questionnaire (Liaison Office in Jakarta amount of 6 questionnaires), questionnaires were invalid is 27 questionnaires filled does not complete and 10 questionnaires again filled incompatible with long-serving criteria. Invalid questionnaires were not included in the subsequent data analysis. The amounts of sample used in this study were 203 respondents to the effective rate of return are $82.52 \%$. After analyzing the data found 18 questionnaires of data outliers. Respondents total 185 for further analysis.

Respondents, consisting of 141 (76.2\%) men and 44 (23.68\%) women. Respondents are Head of regional work units $31(16,8 \%)$, Secretary of the $30(16.2 \%)$, head of section/Head Dept. of Planning 35 (18.9\%), Head of Program 
Development Section 35 (18.9\%), Head of Equipment 25 (14.5\%) and Section Head Equipment 29 (15.7). Education level of respondents consisted of: 49.7\% Tier-1 (85.0\%) and Strata-2 (48.6\%), and Strata-3 (1.6\%).

\subsection{Variable Measurement}

This study uses Participative Budgeting as an independent variable, budgetary slack as the dependent variable and job satisfaction as mediating and moderating variables. These variables were measured by questionnaire that was adopted from previous related research.

\subsection{Participative Budgeting}

Participative Budgeting is the level of involvement and influence on individuals in the budget process. To measure this variable, the researchers used an instrument consisting of 6 items of questions developed by Milani (1975) instrument has a sufficient degree of validity and has been used in previous studies. In this instrument, each respondent was asked to answer six questions using a scale of 1-7. Scale 7 showed the highest level of participation, while the scale of 1 indicates the lowest level of participation.

\subsection{Budgetary Slack}

Budgetary slack is defined as the difference between the amounts of the proposed budget subordinate to the best estimate of the number of organizations. Measurement of budgetary slack used instruments developed by Dunk (1993) with six questions using seven scale. Scale 7 showed the highest level of budgetary slack, whereas a scale of 1 indicates the lowest level of budgetary slack.

\subsection{Job Satisfaction}

Job satisfaction is an individual thing. Each individual has a level of satisfaction varies, as defined by Kreitner and Kinicki (2000), that job satisfaction as effectiveness or emotional response to various aspects of the job. This definition implies that job satisfaction is not a single concept; otherwise one can be relatively satisfied with some aspects of the job and not be satisfied with one or several other aspects. Job satisfaction dimensions measured by instruments developed by Bussing et al. (1999) with ten questions using seven scales. Scale 7 shows the highest level of job satisfaction, while 1 indicates the lowest level.

\section{RESULTS}

\subsection{Factor Analysis}

Data reliability test results show a good enough level of consistency. In reliability test, the consistency at least 0.60 (Ghozali 2013). These results can be interpreted that the questions which measure the construct of participative budgeting, job satisfaction and budgetary slack, the respondents' answers are reliable.

By using Maximum Likelihood (ML) as the model estimates, the number of samples required minimum of 100 and a maximum of 200 (Ghozali 2013). Prior to further testing, conducted the study on indicators that do not meet the criteria. Results of the study showed even though the indicators are excluded from the measurement model, theoretically indicator that residual (meet the criteria) can measure each construct (Hair et al. 2010).

Table 1. Can be seen every construct or the variable has Cronbach's alpha values above 0.60 which distinguishes that interval consistency of variable Participative Budgeting, job satisfaction, and budgetary slack has good reliability in this study. Reliability test results are presented Table 1. 
Table 1. Loading Factors $(\mathrm{N}=185)$

\begin{tabular}{|c|c|c|c|}
\hline $\begin{array}{ll}\text { Factors and Scales } \\
\end{array}$ & Factor 1 & Factor 2 & Factor 3 \\
\hline \multicolumn{4}{|l|}{$\mathrm{PB}=$ Participative Budgeting (Cronbach $\alpha: 0.824)$} \\
\hline PB2 & 0.637 & & \\
\hline PB3 & 0.714 & & \\
\hline PB4 & 0.734 & & \\
\hline PB5 & 0.792 & & \\
\hline \multicolumn{4}{|l|}{ Job satisfaction (Cronbach $\alpha: 0.651$ ) } \\
\hline JS2 & & 0.660 & \\
\hline JS3 & & 0.714 & \\
\hline JS4 & & 0.858 & \\
\hline JS8 & & 0.754 & \\
\hline \multicolumn{4}{|l|}{$\mathrm{BS}=$ Budgetary slack $($ Cronbach $\alpha: 0.861)$} \\
\hline $\mathrm{BS} 2$ & & & 0.693 \\
\hline BS3 & & & 0.723 \\
\hline BS4 & & & 0.750 \\
\hline BS5 & & & 0.849 \\
\hline BS6 & & & 0.720 \\
\hline
\end{tabular}

An indicator is valid if it has a loading factor above 0.5 to construct the destination. In the table above it appears that the value of loading factor of less than 0.5 are indicators of PB1 and PB6 to construct participative budgeting, indicator JS1, JS 5, JS 6, JS 7, JS 9, and JS 10 to construct job satisfaction. Budgetary slack there are three negative question, namely BS1, BS3 and BS6, the respondents' answers were analyzed must be reversed before the answer, just BS3 and BS6 done because BS1 loading factor value below 50\%.

\subsection{Correlation Analysis}

Correlation analyzes were performed to analyze the relationship between variables. The correlation matrix in Table 2 shows there is a strong positive relationship between Participative Budgeting and job satisfaction indicated by the correlation coefficient of 0.234 and significant. There is a negative correlation between Participative Budgeting and budgetary slack with a coefficient of 0.291 and a significant negative correlation. The correlation coefficient values can be seen in Table 2 .

Table 2. Mean, Standard Deviation, Correlation Coefficients

\begin{tabular}{l|c|c|c|c|c|c|c}
\hline \multicolumn{1}{c|}{ Variables } & Means & $\begin{array}{c}\text { Standard } \\
\text { Deviation }\end{array}$ & Min. & Max. & $\mathbf{1}$ & $\mathbf{2}$ & $\mathbf{3}$ \\
\hline Participative Budgeting & 31.56 & 4.993 & 1 & 7 & 1 & & 1 \\
\hline Job satisfaction & 56.16 & 5.720 & 1 & 7 & $0.234^{*}$ & 1 \\
\hline Budgetary slack & 23.61 & 2.042 & 1 & 7 & $-0.312^{*}$ & $0.291^{*}$ & 1 \\
\hline
\end{tabular}

* significant $(0,05)$

\subsection{Assessment of Fit Indices}

Based on the results of the feasibility test model of the value of goodness of fit indices for all the criteria used were Chi-square, Probability, TLI, CFI, GFI, AGFI, CMINDF, and RMSEA has a value of either value is required calculating the goodness of fit because it has a value range expected. The results of the feasibility test SEM models shown in Table 3. 
Table 3. The Goodness-Of-Fit Statistics

\begin{tabular}{l|c|c|c}
\hline \multicolumn{1}{c|}{ Goodness of-Fit Indices } & Suggested in Literature & Results & Description \\
\hline Chi-Square & expected small & 65.620 & Fit \\
\hline Probability & $\geq 0.05$ & 0.352 & Fit \\
\hline GFI & $\geq 0.90$ & 0.950 & Fit \\
\hline AGFI & $\geq 0.90$ & 0.926 & Fit \\
\hline TLI & $\geq 0.90$ & 0.995 & Fit \\
\hline CFI & $\geq 0.90$ & 0.996 & Fit \\
\hline CMINDF & $\geq 2.00$ & 1.058 & Fit \\
\hline RMSEA & $\geq 0.08$ & 0.018 & Fit \\
\hline
\end{tabular}

\subsection{Test of Hypotheses}

Hypothesis testing is the final outputs of empirical SEM full model are presented Table 3. Based on the data processing program AMOS 20.0 SEM result regression weights. According Ghozali (2013) regression weights gives the big picture unstandardized and standardized coefficient for ordinary least square regression equation. The critical ratio value is the same value ordinary least square regression, whereas $\mathbf{P}$ is equal to the probability of significance.

Table 4. Regression Weights

\begin{tabular}{ll|c|c|c|c}
\hline & & Estimate & S.E. & C.R. & P \\
\hline PB & $\Rightarrow$ BS & -0.282 & 0.082 & -3.457 & $0.000^{*}$ \\
\hline PB & $\Rightarrow$ JS & 0.207 & 0.079 & 2.630 & $0.009^{*}$ \\
\hline SS & $\Rightarrow$ BS & -0.234 & 0.088 & -2.642 & $0.008^{*}$ \\
\hline PB $\Rightarrow$ JS & -0.048 & 0.027 & -1.803 & $0.037^{*}$ \\
\hline Moderating $\Rightarrow$ BS & -0.001 & .001 & -1.008 & $0.314^{* *}$ \\
\hline
\end{tabular}

* Significant in $0.05 ; *$ Insignificant

Based on the parameter estimation analysis table 3 the testing effect of Participative Budgeting on budgetary slack, showed significant gains in the value of the critical ratio (cr) negative 3.457 with a p-value of 0.000 . The values have been qualified acceptance of the hypothesis that cr $>1.96$ significance level of 0.05 and a p-value less than 0.05 , so there is no reason to reject the first hypothesis of this study, meaning that Participative Budgeting proved negative budgetary slack significant.

Statistical tests of the hypothesis 2 suspect that Participative Budgeting has positive effect on job satisfaction. Empirical support for this hypothesis, the test results show that the participation of the budget will increase job satisfaction parameter values estimated 0.207 , standard error values 0.079 the critical ratio value of 2.630 , the probability value of 0.009 . Meaning that participative budgeting has significant positive effect to job satisfaction. The hypothesis is accepted.

The second hypothesis is the participation of the budget proposed significant positive effect on job satisfaction. The data processing states that this pathway has a coefficient of 0.207 and the value of the critical ratio value of 2.639 with a p-value of 0.009 , then the statistical variables affect Participative Budgeting on job satisfaction. It can be concluded that the hypothesis proposed in this study accepted.

Statistical tests of the hypothesis 3 suspect that job satisfaction negatively affect budgetary slack. Empirical support for this hypothesis, the test results showed that job satisfaction will decrease budgetary slack of parameter values negative estimated 0.234 , standard error of the value of 0.088 , the negative value of the critical ratio 2.642 , probability 0.008 , and the hypothesis was accepted.

The testing procedure job satisfaction as a mediator variable correlation between participative budgeting and budgetary slack is as follows Baron and Kenny (1986): (a) to estimate the direct effect of participative budgeting to budgetary slack, (b) to estimate the indirect effect simultaneously with SEM. Model namely Participative Budgeting $\Rightarrow$ job satisfaction $\Rightarrow$ budgetary slack. 
The test results showed that coefficients of then participative budgeting direct effect to budgetary slack is equal to 0,282 negative and significant. The result indicates the coefficient indirect effect of participative budgeting to budgetary slack fell to a negative 0.048 but remains significant. It shows form of partial mediation or in other words, job satisfaction partially mediates the effect of participative budgeting to budgetary slack. This form of partial mediation show that job satisfaction is not the only mediator correlation of participative budgeting to budgetary slack but there are other mediating factors (Baron and Kenny 1986; Hair et al., 2010; Kock, 2011). The test results demonstrate support for the hypothesis 4 that job satisfaction indirect effect on budgetary slack. Job satisfaction act as a partial mediator effect of participative budgeting to budgetary slack.

Hypothesis testing conducted by moderation moderated regression analysis (MRA) that estimated by SEM (Kock 2010, 2011). To test the job satisfaction as a moderating variable correlation between Participative Budgeting with budgetary slack, the focus is on the interaction coefficient between Participative Budgeting and job satisfaction. Hypothesis 5 is supported if the interaction coefficient is negative and significant.

The results in Table 3 show that the coefficient of interaction between Participative Budgeting and job satisfaction is not significant with p-value of 0.314 . Overall, these results indicate that the hypothesis of job satisfaction as a moderating correlation between Participative Budgeting and budgetary slack unsupported. Thus, in this study of job satisfaction there is quasi moderator (Ikhsan and Ane 2007).

\section{CONCLUSION}

This study examines job satisfaction as mediating variables and relationship moderation of Participative Budgeting with budgetary slack in the provincial goverment of North Maluku, Indonesia. Results of the analysis of a direct relationship between participative budgeting on budgetary slack can be derived. It has meaning that the higher the subordinates involved in the budgeting process, its can pressure / lowered budgetary slack. These results are consistent with (Hussein 2011).

Based on data analysis and discussion, the study found that job satisfaction may mediate correlation between participative budgeting and budgetary slack in the preparation of local government budgets in North Maluku province. This is indicated by a significance level of 0.037 . Hypothesis testing results show that the high level of job satisfaction of a subordinate can reduce slack. However, job satisfaction variables instead of moderation in this study because the value is far above the significance level of 0.05 , was 0.314 . For future research of job satisfaction variables advised to be independent variables.

Eventually, this results implied on the involvement of the Head of Department and subordinates level in the preparation of the budget. This is based on the underlying assumption of their believe to the senior. Consequently, the such assumption will make them are valued, involved and given the opportunity to express their opinions in the budgeting process. The involvement of the Chief and the head give motivational impact for them, making the budget process as their personal responsibility, goals and striving to achieve budget goals.

Participative budget enables the sector publics to reduce the budgetary slack associated with the individual works. Budget managers engagement impacts on sharing of inter-unit information related to the work to make optimal decisions in achieving common objectives. Additionally, the involvement of the chief and the head of the budget has proven capable of bridging the necessary strategic policies in the framework of the process of job evaluation and targeting of the next period performance.

\section{AUTHOR BIOGRAPHIES}

Suleman H. A. Kahar, Doctoral Program of Economics, Diponegoro University, Jl. Erlangga Tengah No. 17 Semarang, Indonesia. E-mail: sule_kd@yahoo.co.id

Abdul Rohman, Faculty of Economics and Business, Diponegoro University, Jl. Prof. H. Soedarto, SH, Tembalang, Semarang, Indonesia. 
Anis Chariri, Faculty of Economics and Business, Diponegoro University, J1. Prof. H. Soedarto, SH, Tembalang, Semarang, Indonesia.

\section{REFERENCES}

Baron, R. M., and D. A. Kenny. 1986. The Moderator-Mediator Variable Distinction in Social Psychological Research: Conceptual, Strategic, and Statistical Considerations. Journal of Personality and Social Psychology 51 (6):1173-1182.

Basri, Y. M. 2010. Effect of budgeting participation and job relevant information to the budget slack Riau provincial government. Journal of Public Administration 10 (1): 69-77

Brownell, P. 1982. A Field Study Examination Of Participative Budgeting And Locus Of Contro.l The Accounting Review 57 (4):766-777.

Bussing, A., T. Bissels, V. Fuchs, dan K.-M. Perrari. 1999. A Dynamic Model Of Work Satisfaction: Qualitative Approaches. Human Relations 52 (8):999-1027.

Cammann, C. 1976. Effects Of The Use Of Control Systems. Accounting, Organizations and Society 1 (4):301-313.

Chong, V. K., Eggleton, I. R., \& Leong, M. K. (2006). The multiple roles of participative budgeting on job performance. Advances in accounting, 22, 67-95.

Collins, F. 1978. The Interaction Of Budget Characteristics And Personality Variables With Budgetary Response Attitudes. The Accounting Review 53 (2):324-335.

Djasuli, M., and N. I. Fadila. 2011. Information interaction effect of asymmetry organizational culture group cohesiveness and motivation in the causal relationship among Budgeting Participation and Budgetary Slack. Proceeding Pesat 4:1-6.

Dunk, A. S. 1993. The Effect Of Budget Emphasis And Information Asymmetry On The Relation Between Participative Budgeting And Slack. The Accounting Review 68 (2):400-410.

Ghozali, I. 2013. Structural Equation Modeling; Theory concepts and applications with amos program 21. Semarang Agency Publisher: Diponegoro University.

Govindarajan, V. 1986. Impact of Participation in the Budgetary Process on Managerial Attitudes and Performance: Universalistic and Contingency Perspectives. Decision Science 17:496-516.

Hair, J. F., W. C. Black, B. J. Babin, and R. E. Anderson. 2010. Multivariate Data Analysis. 7 ed: Person Prentice Hall. All Rights Reserverd.

Halim, A., and S. Abdullah. 2008. A Study of the Capital Expenditure Budget of Local Governments in Relation to Maintenance Expenditures and Sources of Income. Journal of Government Accounting 2 (2): 17-32.

Husain, SP 2011. The effect of Participative Budgeting on Budgetary Slack and Organizational Commitment as Moderating Variable. Innovation 8 (3): 102-114.

2014. The Effect of Structural Official Participation in the Preparation of the Budget Against Budgetary Slack Studies on Work Unit District / City in the Province of Gorontalo. Innovation 10 (1): 1-16.

Ikhsan, A., and L. Ane. 2007. Influence of Participative Budgeting on Budgetary Slack Using Five Moderating Variables. National Symposium Paper Accounting X, Makassar.

Jermias, J., \& Setiawan, T. (2008). The moderating effects of hierarchy and control systems on the relationship between budgetary participation and performance. The International Journal of Accounting, 43(3), 268-292

Jaya, M. F. D., and T. Rahardjo. 2013. The Effects of Participative Budgeting, Asymmetric Information, Budget Emphasis, and Organizational Commitment on Budgetary Slack in Government Pasuruan City. 1-29.

Jensen, and W. H. Meckling. 1976. Theory of The Firm: Managerial Behavior, Agency Costs And Ownership Structure. Journal of Financial Economics 3 (4):305-360.

Kenis, I. 1979. Effects of Budgetary Goal Characteristics on Managerial Attitudes And Performance. The Accounting Review 15 (4):707-721.

Kock, N. 2010. Using Warppls In E-Collaboration Studies: An Overview Of Five Main Analysis Steps. International Journal of eCollaboration 6 (4):1-11.

2011. Using Warppls In E-Collaboration Studies: Mediating Effects, Control And Second Order Variables, And Algorithm Choices. International Journal of e-Collaboration 7 (3):1-13.

Kreitner, R., and A. Kinicki. 2000. Organization Behavior edited by 5. USA: Mc Graw-Hill.

Kren, L. 2003. Effects Of Uncertainty, Participation, And Control System Monitoring On The Propensity To Create Budget Slack And Actual Budget Slack Created. Advances in Management Accounting 11:143-167.

Leach-López, M. A., Stammerjohan, W. W., \& Sang Lee, K. (2009). Budget participation and job performance of South Korean managers mediated by job satisfaction and job relevant information. Management Research News, 32(3), 220-238.

Lukka, K. 1988. Budgetary Biasing In Organizations: Theoretical Framework And Empirical Evidence. Accounting Organizations and Society 13:281-301.

Maiga, A. S. 2005. The Effect Of Manager's Moral Equity On The Relationship Between Participative Budgeting And Propensity To Create Slack: A Research Note. Advances in Accounting Behavioral Research 8:139-165. 
Maiga, A. S., and F. A. Jacobs. 2008. The Moderating Effect of Manager's Ethical Judgment on The Relationship between Participative Budgeting and Budget Slack. Advances in Accounting 23:113-145.

Mardiasmo. 2002. Public Sector Accounting. Andi Offset: Yogakarta.

Merchant, K. A. 1985. Budgeting and the Propensity to Create Slack. Accounting Organization and Society 10:201-210.

Milani, K. 1975. The Relationship Of Participation In Budget-Setting To Industrial Sopervisor Performance And Attitudes: A Field Study The Accounting Review:274-284.

Nouri, H., \& Parker, R. J. (1998). The relationship between budget participation and job performance: the roles of budget adequacy and organizational commitment. Accounting, Organizations and Society, 23(5), 467-483.

Nouri, H. (1994). Using organizational commitment and job involment to predict budgetary slack: A research note. Accounting, Organizations and Society, 19(3), 289-295

Nor Yahya, M., Nazli Nik Ahmad, N., \& Hamid Fatima, A. (2008). Budgetary participation and performance: some Malaysian evidence. International Journal of Public Sector Management, 21(6), 658-673.

Onsi, M. 1973. Factor Analysis Of Behavioral Variables Affecting Budgetary Slack. The Accounting Review 46 (3):535-548.

Ozer, G., and E. Yilmaz. 2011. Effects Of Procedural Justice Perception, Budgetary Control Effectiveness And Ethical Work Climate On Propensity To Create Budgetary Slack. Business and Economics Research Journal 2 (4):1-18.

Siegel, G., and H. R. Marconi. 1989. Behavioral Accounting. Cincinnati Ohio: South-Western Publishing Co.

Vemy, A., G. Pagalung, dan Syarifuddin. 2011. The Influence of The Interaction Between Organisation Commitment Participative Budgeting, and Work Involvement on The Consistency of Budget Use in The Health Office of West Sulawesi Province. 1-15.

Young, S. M. 1985. Participative Budgeting: The Effects Of Risk Aversion And Asymmetric Information On Budgetary Slack. Journal of Accounting Research 23 (2):829-842.

Yuwono, I. B. 1998. The Influence Of Organizational Commitment And Environmental Uncertainty On The Relationship Between Participative Budgeting And Budgetary Slack. Journal Of Businesses And Accountants 4. 


\section{APPENDIX 1}

The Relationship of Participative Budgeting and Budgetary Slack (Hypothesis 1)

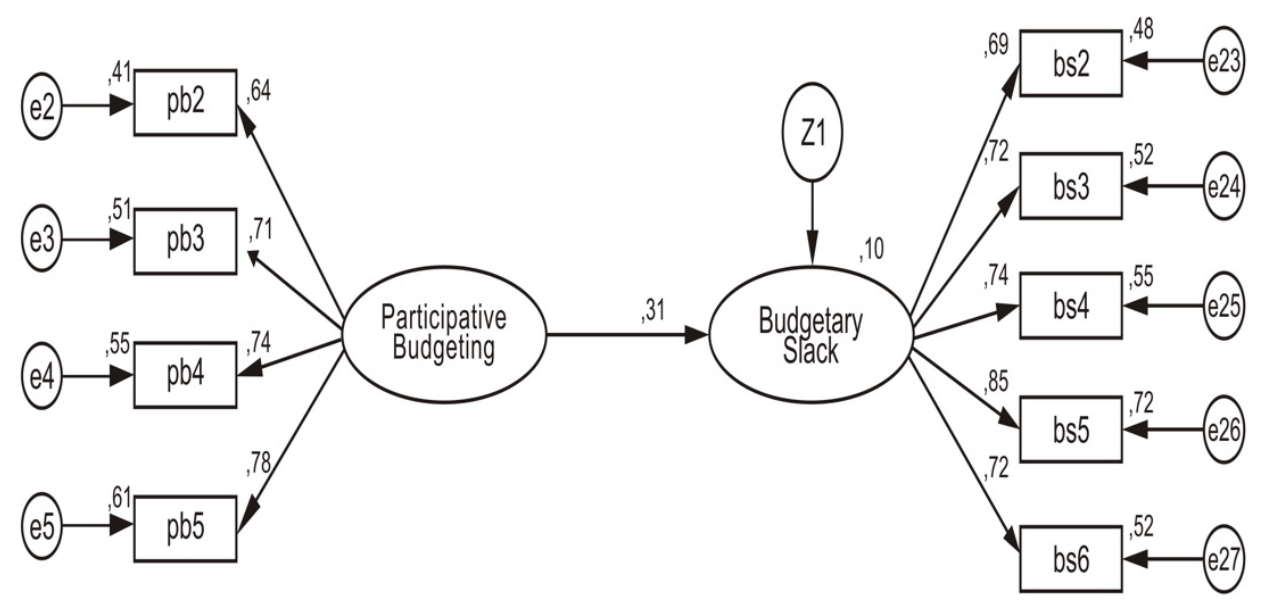

APPENDIX 2

The Roles of Intervening Variable (Hypothesis 2, 3 and 4)

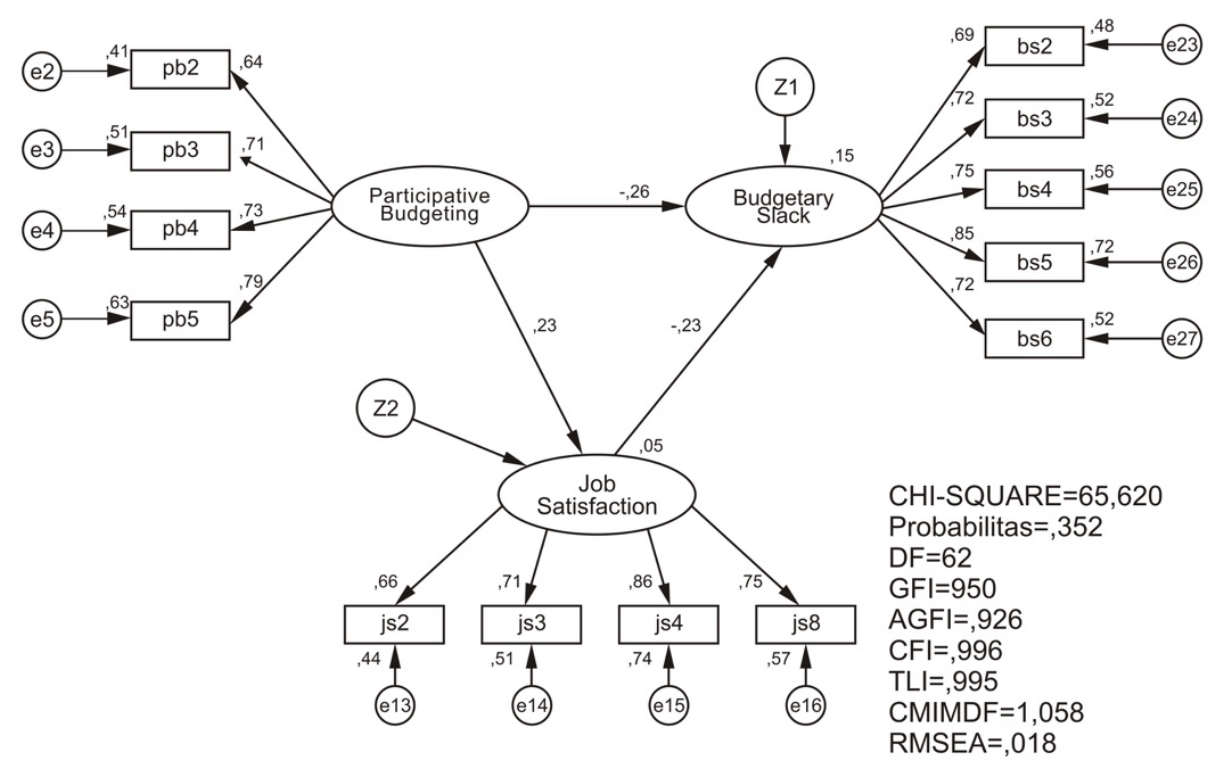




\section{APPENDIX 3}

The Relationship of Participative Budgeting and Budgetary Slack moderated by job satisfaction (Hypothesis 5)

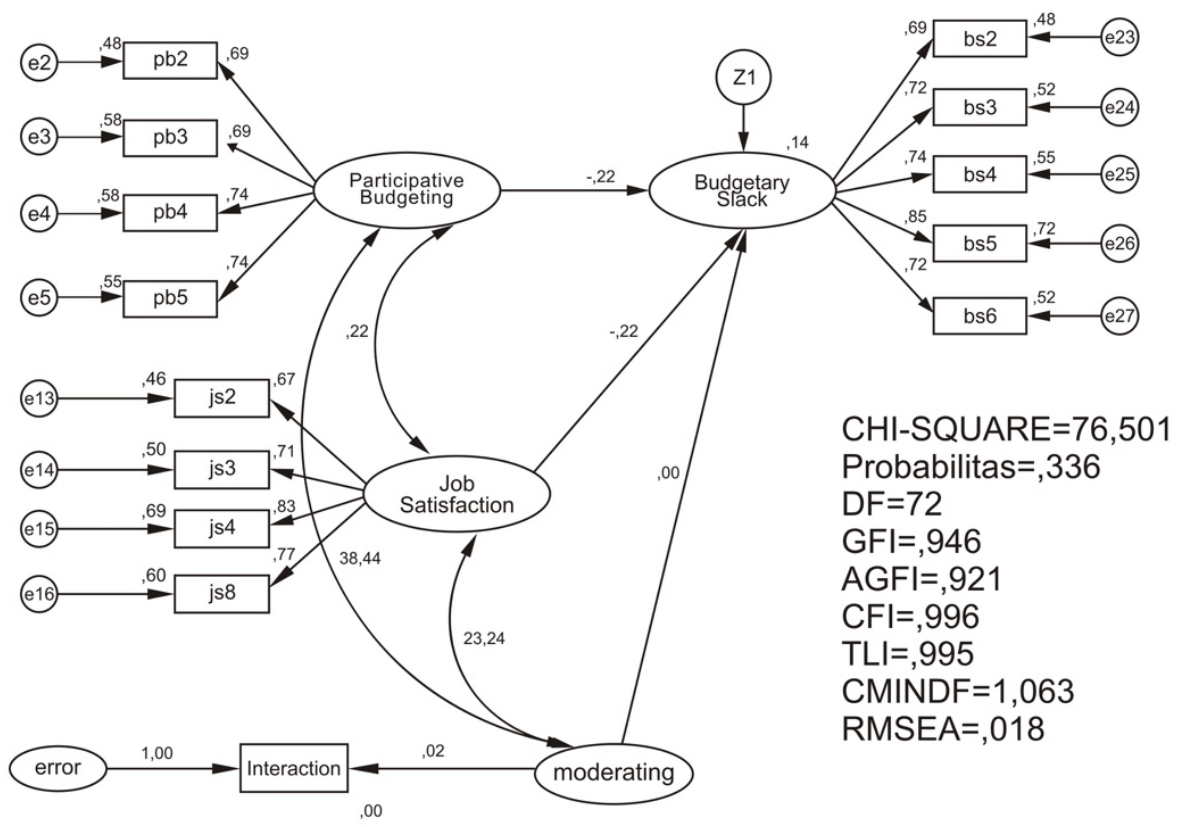

